\title{
Origins of research methodology, Buddhism and the Four Noble Truths
}

\author{
Laksiri Fernando* \\ Former Senior Professor, Department of Political Science and Public Policy, University of Colombo, Colombo, Sri Lanka.
}

\begin{abstract}
Emerging academic studies addressing the interface between Buddhism and modern science is the 'major premise' of this research article. However, when the similarities so far uncovered are closely observed, they mostly belong to findings or theories and not so much on the overall methodology. Based on those studies as well as independent research, this article proposes that there is much to learn from Buddhism for modern day research methodology, particularly in the Social Sciences sphere. The article demonstrates that particularly the Four Noble Truths (Dhammacakkappavattana-sutta in Sutta-pitaka) constitute a framework for research designing, investigation and particularly problem solving: Dukkha as problem identification, Samudaya as causal investigation, Nirodha as possible or required solutions and Magga as recommendations or pathways for desired solutions. The other two methodological components identified and discussed in this investigation are the importance of independent observation (Kalama-sutta) and dialectical causality or dependent origination/arising (Paticcasamuppada). The article concludes that if the methodology of the Four Noble Truths is important in uncovering and investigating new knowledge, the guidelines in Kalama-sutta are important in verifying and accepting or rejecting existing knowledge. On the other hand, the 'dependent origination' is most fundamental to any complex social research or investigation.
\end{abstract}

Keywords: Methodology, science, research, Buddhism, objectivity, causality.

\section{INTRODUCTION}

The interface between Buddhism and modern science is an emerging field of study addressed by many Western and Eastern scholars and authors; more so by the former than the latter (Ricard and Thuan, 2001; Wallace, 2001; Wallace, 2003; Flanagan, 2007; Lopez, 2008; 2012; Barash, 2013; Cho and Squier, 2015) ${ }^{1}$. Some of the already available revelations, in fact, are inspirational for further studies on the subject. The interface was identified previously by some Sri Lankan authors, although the endeavour was not consistently carried forward. One exception, however, is Fonseka (2011) who has continued to investigate the scientific aspects of the Buddha's teachings and wrote about them in simple and cohesive terms. As Jayatilleke (1984: 9) argued previously, early Buddhism emphasises the importance of the 'scientific outlook' in understanding the nature of man and the universe among many other phenomena and relationships. As he said,

"To take this last point first, we find for instance, that the early Buddhist conception of cosmos, is in essence similar to the modern conception of the universe."

For example, in several Suttas, there are many descriptions of hundreds and thousands of suns, moons and earths, and hundred thousands of middling world systems or galaxies. This is very much similar to what the modern astronomers have found as the Milky Way and beyond ${ }^{2}$. The Buddhist perception goes very well with cosmology since Copernicus or Galileo. On human condition and intellectual feelings for a 'cosmic outlook' or 'cosmic religion', even Albert Einstein seemed to have appreciated Buddhism that he learnt from Schopenhauer ${ }^{3}$.

Rather a path breaking study was published, by a renowned biologist David Barash, titled, Buddhist Biology in 2013. The subtitle of the book is also important: Ancient Eastern Wisdom Meets Modern Western Science. In his introduction to the study, noting the meeting points between Buddhism and Biology, he has said the following.

"Among many commonalities between Buddhism and biology, probably the most important is their shared recognition of interconnection between organism and environment. This principle (pratitya-samutpada in Sanskrit) is 
usually translated as 'dependent co-origination', 'dependent arising', or 'interdependent origination.” (Barash, 2013: 20)

The similarities between Buddhism and modern science highlighted in almost all the above studies and others, however, are in terms of findings or teachings in the case of Buddhism, and not particularly in terms of methodology or approaches. Or at best, few or passing comments on methodology were secondary to the themes or topics that they were exploring. When Ven. Nyanaponika Thera (1962: 42) was explicating the mental training methods on Buddha's way to mindfulness, he said that,

"This method of Bare Attention, so helpful to mind-knowledge, and through it, to worldknowledge, tallies with the procedure and attitude of the true scientist and scholar." ${ }^{4}$

Although this comment was on methodology, it was a passing one, though crucially important, in his handbook on Buddhist meditation.

There are many other areas of study where similarities with Buddhism could be found. For instance, the congruence between modern philosophy and Buddhism is undoubtedly more profound than the interface between Buddhism and modern science because Buddhism, other than being a 'religion' in its common usage, is a philosophy in itself (Kalupahana, 1976; Siderits, 2007). On this subject, Davids (2005: 5) apparently differed from Max Muller in characterising Buddhism. Davids, in his initial work in 1896, stated that none of the five attributes that Muller identified with religion is found in Buddhism and thus it is a philosophy than a religion ${ }^{5}$. This is not to deny the soteriological purposes of Buddhism. However, the purpose of the present study is different, being tracing the usefulness of Buddhist Philosophy for research methodology. Some other areas where inspirations could be drawn from Buddhism are Psychology (De Silva, 1973; Dockett et al., 2004), Education (Mookerji, 2003; Nithiyanandam, 2004), Economics (Sivaraksa, 2011; Evans, 1994), Political Theory (Gard, 1956; Ratnapala, 1997; Dissanayake, 1999) and Peace Studies (Galtung and Ikeda, 1995; Mun and Green, 2006).

It is in the background of the above mentioned studies that the purpose of this article is located. After briefly stating the purpose of the study, this article thus explains the problem/focus of the study in justifying the necessity to investigate methodological importance of Buddhism for modern day research. It is in the same vein that the genesis of research methodology and a brief comparison with the Buddha's contemporaries (i.e. Aristotle) are presented to give a comparative and a historical perspective. The focus of the article in that context is on the origins of research methodology. The crux of the article thereafter follows, focusing and explaining the methodology of the Four Noble Truths (hereinafter mostly called FNT) and other teachings of the Buddha on 'independent investigation/verification' and 'dependent origination of causality'. Nevertheless, the main argument of the article, highlighting Buddhism as a methodology, runs through from the beginning to the end. Needless to say, the article makes its own overall observations and conclusions at the end.

\section{PURPOSE OF THE STUDY}

The main reason to record the connection between Buddhism and some of the important areas of the present day academic studies in the Introduction was to emphasise the fact that without a 'scientific outlook', Buddhism would not have been in a position to come up with such long lasting theories, hypotheses or propositions, whether it is Cakkavata (cosmos), Anicca (impermanence), Paticcasamuppada (dependent origination causality), Mahasammata (social-contract) or Majjhimapatipada (middle-path). The next reason is to show that although many similarities were shown between Buddhism and scientific propositions or findings, hardly any systematic attempt had been made to draw lessons from Buddhism to enrich the present day research methodology or to show the similarities ${ }^{6}$.

The present article thus proposes that the 'scientific outlook' of Buddhism, although clouded with legendary interpretations at times, could primarily be located in the FNT and in Kalama-sutta, Paticcasamuppada etc., which would immensely be useful in the present day research methodology and scientific investigations. Moreover, what can be seen in Buddhism is not so much of theories or propositions, but a methodology and approach without static notions or dogmas. It is important to note the distinction that the Buddha made between Paramatta Sacca (fundamental truth or truth in ultimate sense) and Sammuti Sacca (conventional truth). What is fundamental or fundamentally 'scientific' is the FNT. All others are relative or conventional and subject to continuous impermanence. While it is true that Buddhism is primarily a 'theory of the mind of man' (women included), there is no reason to presume why the methodology in general could not be applied to society or Social Sciences. Society and Social Sciences are selected for this inquiry and exposition not because of any integral reason, but that is the field of study that 
this author is familiar or competent with. Moreover, it might be possible that the application of the 'scientific outlook' prevalent in Buddhism is more applicable to Social Sciences than to Natural Sciences since the main focus of the Buddha was on the 'man and his/her mind' in society.

\section{THE PROBLEMATIC AGAIN}

Research might be defined, in general terms, as "systematic investigation to gain knowledge about a problem, phenomenon, topic or a relationship" (Kothari, 2004:1; De Poly and Gitlin, 2011: 3). The word 'research' derives from the French word recherché, meaning "to search deeply with intensity" (Rodgers and Yee, 2015: 11), with previous origins in Latin. In this sense, the Buddha's endeavor was 'to search' and search for the 'truth'. One might rightly think that the Buddha cannot be considered a 'researcher' in the modern definition of the term, and he, like Socrates of the same period (Armstrong, 2007), was seeking knowledge through contemplation and observation?. That is largely true; however, his voyages in the whole of the Gangetic plain (now Uttar Pradesh, Bihar, Nepal and even beyond) was done not only for teaching, but also for knowledge seeking and observation. As many stories in the Dhammapada and other texts reveal, he was continuously questioning what he observed and expressing his analytical discourses ${ }^{8}$.

It is customary for scholars to trace the origins of research methodology to ancient Greece and to Socrates. The Buddha was of the same period from the East and the Ganges. The endeavor was to seek knowledge and in this context, the Buddha appears to be more specific than Socrates in trying to grasp knowledge and grasp it systematically. His main endeavor was to understand Dukkha (human suffering) and trying to find Magga (means) to overcome that suffering, one may say, in a spiritual/religious sense. The methodology that he used in this endeavor at that time or even today, however, is quite exemplary in any research, particularly in the social sphere. Today, it is obvious that research is an activity, and a human activity for that matter, and for that, it is increasingly clear that many lessons could be drawn from Buddha's teachings, for research and research methodology. As a human activity, research is bound to have possible error. No human is infallible. Therefore, a systematic methodology is important in research to avoid error as much as possible. There is no single methodology, but several of them, and the Buddhist methodology could be considered at least as one. It is in this context that what the Buddha said about Vidya (science or knowledge) and its methodology is important. As Wallace (2001: 46) said in reference to Tantric Buddhism,
"The concept of science in the kalacakratantra is indicated by the Sanskrit vidya, meaning 'knowledge'. Already in some of the early Buddhist expositions on vidya, the term signifies more than knowledge regarding the Four Noble Truths. In the Nettipakarana, the definition of vidya includes such concepts as investigation (vicaya), scrutiny or observation (apaparikkha), and correct views or theories (sammaditti)."

The plurality of methodology has arisen, whether in Buddhism or modern day research, because of the diversity of matter - phenomena or relationships that is being investigated. The diversity may require different methods to be used on the same phenomenon or a particular method selected depending on the nature of the matter that is under investigation. For example, there is a considerable difference between natural phenomena and social phenomena. Thus the methods of Social Sciences differ from the methods of Natural Sciences, e.g. in Physics or Chemistry. Again the different branches of Social Sciences or Natural Sciences differ from one another in terms of the methods that they employ for research or systematic investigation. This is also compatible with Buddhist philosophy or practice. For example, the Buddhist approach to 'mindfulness' is multiple. These approaches are also directly related to the methods of acquiring knowledge. As Dunne (2015: 251) argued,

"In brief, Buddhist traditions promote multiple approaches to mindfulness, and these approaches involve different techniques that occur with different theoretical accounts."

It is also his opinion that different present day approaches in Buddhism, i.e. Theravada, Mahayana or Tibetan and Zen are related to these multiple approaches enunciated in early Buddhism. What might be important both in Buddhism and in research methodology therefore is to understand and accept the 'overlap and interbreed' of different approaches, but finally to grasp the 'unity and coherence' of overall methodology in seeking human knowledge.

Today, research methodology is in fact a generic term to cover a host of research methods and in addition indicating the philosophy behind the various research methods that is used, under contemporary circumstances. As you could have already understood, this article focuses mainly on the second part of the above problematic or interpretation to mean the 'philosophy behind' various research methods. The rationale for the preoccupation of this article on 'research methodology' derives from the 
fact that methodology is crucial to successful research. There cannot be any research, even bad ones, without a 'methodology'. It primarily means the theory and philosophy behind. It denotes the use or the process of research based on the theory and philosophy also employing relevant methods. The selection of an appropriate methodology - not any methodology - is the key to success. The difference between bad research and good research might depend on the researcher's grasp of research methodology. The quality of research, the knowledge outcomes of that enterprise, or the 'scientific' applicability of the conclusions derived, would largely depend on the methodology that it pursues. Before the selection of any particular methodology or methodologies there is a pressing need to understand the genesis or the philosophy of research methodology in generic terms.

\section{A COMPARISON OF THE GENESIS OF THE SCIENTIFIC METHOD}

As we have already stated, many scholars accept that systematic or structured attempts to gain knowledge on various natural and social phenomena date back to the Greek period. What is neglected until recently is the recognition of contributions from other civilisations or philosophers/philosophies, perhaps more or equally profound, as the Greek contributions. It is apparent that rudiments of these attempts existed in many civilisations before and after, and the Buddhist philosophy is one of the important ones amongst Zoroastrian (Boyce, 1984) and Confucian (Schuman, 2015) initiatives.

In the case of ancient Greece, Socrates, Plato and Aristotle were three prominent figures who contributed to knowledge through contemplation and investigation. Socrates (470-399 BCE), like the Buddha, sought reflective wisdom but never left his own writings. It was left for his disciples, in particular Plato, to record and preserve them. In the case of the Buddha, his teachings were transformed into Suttas and carried forward by oral tradition and the written records started to emerge in Pali some centuries later. Therefore, his teachings became further enriched over the centuries. As Dalai Lama (Tenzin Gyatso) has said,

"Suppose that something is definitely proven through scientific investigation, that a certain hypothesis is verified or a certain fact emerges as a result of scientific investigation. And suppose, furthermore, that fact is incompatible with Buddhist theory. There is no doubt that we must accept the result of the scientific research." (quoted by Barash, 2013: 3)
One factor that contributed to the development of Greek philosophy was its continuity. Plato was there after Socrates, followed by Aristotle. This advantage, unfortunately, was not there for the Buddha. Plato (428-347 BCE), was the founder of the Academy in Athens and the author of the Republic among many other writings. Plato's Academy was undoubtedly the first research institute so far known in history ${ }^{10}$. However, it was his student Aristotle (384-322 BCE) who invented the first systematic method of investigation and reasoning called 'Syllogism'. Perhaps Plato could be considered the founder of humanities, but not Social Sciences. The difference between Plato and Aristotle in a way is the difference between humanities and Social Sciences. Plato's approach did not stick to a particular method. It was contemplative and imaginative. He was more concerned about normative matters than the actual ones. In comparison, in the case of the Buddha's teachings one could see a combination of normative matters and actual ones. This could be seen in the way he enunciated the Four Noble Truths, the dependent origination (Paticcasamuppada) and what is contained, for example, in the Kalama-sutta.

Aristotle is important for our discussion not because of his various socio-political theories or arguments, but because of his methodology or Logic which became compiled in The Organon (Jones, 2012) ${ }^{11}$. To put it simply, according to Aristotle, knowledge develops from the known to the unknown ${ }^{12}$. His method is mostly explained as a linear logic with a major premise, then a minor premise and through which a conclusion could be arrived at. Two examples could be given by drawing from Aristotle himself as shown in Table 1 below $^{13}$.

Table 1: Logic examples by Aristotle

\begin{tabular}{ll}
\hline Valid and Acceptable & Valid and Unacceptable \\
\hline All men are mortal $(\mathrm{A}=\mathrm{B})$ & He who sits, writes $(\mathrm{A}=\mathrm{B})$ \\
Socrates is a man $(\mathrm{C}=\mathrm{A})$ & Socrates is sitting $(\mathrm{C}=\mathrm{A})$ \\
Socrates is mortal $(\mathrm{C}=\mathrm{B})$ & Socrates is writing $(\mathrm{C}=\mathrm{B})$
\end{tabular}

Both arguments, according to Aristotle, are valid or logical but the second obviously defies even the common sense. It is not that Aristotle advocated accepting all arguments logically valid as true (like the second one), but he considered most of the unacceptable arguments depend on the fallacy of the major premise or the connection between the major premise and the minor premise. How do you arrive at major premises? In many instances, he said, it is by convention. It is this kind of a reasoning that the Buddha questioned particularly in Kalama-sutta, perhaps because similar thinking or 
methodology was prevalent during his time in India with which he disagreed. The Buddha's advocacy was more towards 'objective observation' and 'scientific verification' and not 'logical consistency,' or 'convention' in the case of major premises.

On the second argument, Aristotle said "Now we may demolish the proposition 'Socrates is sitting', and still be no nearer a solution". Accordingly, it is not this that needs to be demolished, but that "He who sits, writes: for he who sits does not always write" (Jones, 2012: 336). From these arguments from Aristotle, it is also clear that he considered that 'knowledge' or 'truth' derives through 'arguments' and 'demolition of arguments'. This is again where the Buddha or the Buddhist methodology differed. There are many other weaknesses in the Aristotelian logic. One of the major critics of Aristotle was Francis Bacon (1561-1626) who elaborated the inductive reasoning and the modern scientific method. Even before going to that extent, it was clear that Aristotelian logic was too simplistic with rather a black and white distinction of the reality: if one is true, the other is false. In Buddha's philosophy, the reality is much more complex. The following was what Ven. Nyanaponika Thera (2008: 74) said on the subject which was also stated before by Jayatilleke (2008: 350$)^{14}$.

"Today with the discovery of many-valued logic and the consequent realization that Aristotelian logic is only one of many possible systems, the significance of this Buddhist logic of four alternatives (catuskoti) could be better understood. Briefly, this is a two-valued logic of four alternatives unlike Aristotelian logic, which is a two-valued logic of two alternatives."

The examples that Ven. Nyanaponika Thera gave for 'four alternative conclusions' were the following (with few modifications): (1) the universe is infinite in all dimensions; (2) the universe is finite in all dimensions; (3) the universe is finite in some dimensions and infinite in other dimensions; and (4) the universe is neither finite nor infinite. Therefore, when the logical reasoning alone is used there can be several tentative conclusions or hypotheses that people can arrive at according to the Buddhist philosophy. Then how can one come to a scientific conclusion? This is where, in my opinion, that the method, the structure and the 'logic' of the FNT is useful.

\section{FOUR NOBLE TRUTHS (FNT)}

The Four Noble Truths (FNT) can be considered as the foundation of the Buddhist philosophy and thought. It was apparently the first teaching of the Buddha which appears in Dhammacakkappavattanasutta in Sutta-pitaka. In the strict interpretation of the FNT, there cannot be any doubt that the primary aim was to explain how to achieve Nibbana or individual emancipation. However, considering the way in which Buddhist teachings and philosophy have evolved, there is nothing wrong in interpreting the FNT in the way they are interpreted here. The reasons are as follows: (1) Buddhism is primarily a philosophy than a religion; (2) As the Buddha was addressing many existential, social and environmental issues of the people, after the attainment of enlightenment or delivering the first teaching, it is possible to assume that he applied or used the same methodology to interpret other issues and problems; (3) The way the Four Noble Truths are interpreted here does not diminish the value of Buddhism but enhances it.

In that sense and interpretation, the FNT is primarily about 'knowledge' and 'knowledge acquisition'. That is also the primary purpuse of research. According to a very reliable translation of Dhammacakkappavattana-sutta by Thanissaro Bhikkhu ${ }^{15}$, the value of the middle path was emphasised as 'leading to calm, to direct knowledge and self-awakening'. This is of paramount importance to today's research. The translation records,

"Avoiding both of these extremes, the middle way [was] realized by the Tathagatha - producing vision, producing knowledge - leads to calm, to direct knowledge, to self-awakening and to unbinding." (Thanissaro Bhikkhu, 1993)

It is important to emphasise the key phrases: 'producing vision', 'producing knowledge' and 'direct knowledge' if not 'self-awakening' or 'unbinding'. Even one can argue that a kind of 'middle path' is crucially important for a present day researcher when particularly researching on controversial political, economic, conflict or ethnic matters.

The second section of the Sutta is about the noble eightfold path, further explicating the middle path. It goes as follows.

"And what is the middle way realized by the Tathagata...Precisely this Noble Eightfold Path: right view, right resolve, right speech, right action, right livelihood, right effort, right mindfulness, [and] right concentration." (Thanissaro Bhikkhu, 1993)

Now, one can argue that this is about ethics and about how to pursue a righteous living. Nevertheless, if a middle path 
is important for research in the midst of controversial and conflictual issues, cannot one assume that at least some of the 'paths' enumerated by the Buddha are important for research as well? The present author answers the question in the affirmative. If not 'right livelihood', the other attributes, more or less, might be important for a successful and a useful researcher. Research does not happen in isolation, but within a dedicated academic life. Therefore, even 'right livelihood' might indicate a necessary broader condition for a researcher's proper deliverance of duties, following academic ethics of that particular context.

Today we emphasise the rights of academics and researchers, particularly, in the form of freedoms. Academic freedom is one of the key areas rightly emphasised by academics, because of restrictions from the state and political authorities in any country ${ }^{16}$. However, the Buddha has given a different angle to the equation; emphasising not merely duties, but also the right way those attributes, faculties or rights should be exercised. This is also about objective, independent and 'scientific' manner in which, not only the intellectuals, but also the ordinary people should conduct their lives.

Is there any possibility of interpreting the core elements of FNT beyond the existing interpretations? Or is it correct to do so? As Ven. Walpola Rahula explained,

"But there are innumerable places in the early Buddhist scriptures where they are explained again and again, with greater detail and in different ways.” (Rahula, 1987:16)

He himself interpreted Dukkha not as mere 'suffering', but as problems of life as they are, objectively. It is about the diagnosis of life's problems correctly. He said,

"But the term Dukkha as the First Noble Truth, which represents the Buddha's view of life and the world, has a deeper philosophical meaning and connotes enormously wider senses" (Rahula, 1978:17)

Some other words he gave for the meaning of Dukkha were, 'imperfection', 'impermanence', 'emptiness', and 'insubstantiality'. It is true that the present day research does not address the issues of 'imperfection', or 'impermanence', in any fundamental manner. Most of the terms used to explain the 'drive for' research are 'problems', 'puzzles', 'enigmas', 'conundrums' or 'dilemmas'. However, they are directly and indirectly related to the issues of 'imperfections' and 'impermanence' that Ven. Walpola Rahula talked about. The research or the scientific methodology that John Dewey advocated has a close resemblance to what the Buddha enunciated as an overall scientific outlook in the FNT to understand the 'impermanent' and 'imperfect' world reality. 'Bewilderment' is the word often used by Dewey to explain the intellectual drive for research and for the necessity to have a logical and scientific approach (Hook, 2008: 89).

It is well known that Visuddhi Magga compared Dukkha with disease: "the truth of the origin of Dukkha with the cause of the disease, the truth of the extinction quote of Dukkha with the cure of the disease, and the truth of the path with the medicine" ${ }^{17}$. It was Taniguchi (1994) who elaborated the logic in the modern context;

"The teaching of the Buddha are fourfold. He diagnosed human illness, discovered its cause, defined good health, and developed the methodology for treating and preventing illness. This formula, which is called the Four Noble Truths (Ariyasaccani) in Buddhism, has a structure distinctively paralleling that of medical science: (1) diagnosis of the illness, (2) etiology of the illness, (3) healing, and (4) therapeutics for the illness." (Tanighchi, $1994: 31$ )

It is the contention of this article that the 'structure and logic' of the FNT parallel or even epitomise a research methodology. The latter contention that it 'epitomises' a research methodology is rational given the fact that the Four Noble Truths are the basis of the Buddha's theory of knowledge (epistemology). Any good theory of knowledge could be a basis for a research methodology. One example is Marxism and what can be gleaned by understanding and elaborating the core elements of FNT might prove more profound and useful without rigidity, dogmatism or reductionism.

\section{CORE ELEMENTS AND COMPARISON}

There cannot be any dispute that the Buddha discovered the (four component or four stage) methodology of the Four Noble Truths in order to understand and analyse humanity's major conundrum/puzzle that he called Dukkha. Although the effort was to understand the problem at the individual level, the application of it at the social level is so obvious. If the examples of the major contemporary issues such as poverty, ethnic conflicts, war or environmental disasters are considered, the application of the methodology looms larger and even those issues could be called part of 'Dukkha,' literally. 
Table 2 demonstrates the four components/stages and their possible interconnections.

Table 2: Struture of Four Noble Truth methodology

\begin{tabular}{cc}
\hline \multicolumn{2}{c}{ Structure of FNT Methodology } \\
\hline 1 & 3 \\
Dukkha (research problem/s) & Nirodha (solution/s) \\
\hline 2 & 4 \\
Samudaya (cause/s of the prob- & Magga (pathways to achieve \\
lem $/ \mathrm{s}$ ) & solution $/ \mathrm{s}$ ) \\
\hline
\end{tabular}

According to Dhammacakkappavattana-sutta, the order of the stages or components follows the pattern of (1) Dukkha; (2) Samudaya; (3) Nirodha; and (4) Magga. These are equivalent to (1) the problem/s of research; (2) necessary analysis of the causes; (3) identification of the solutions; and (4) proposed pathways to achieve the solutions. When we focus on the original Pali texts (as translated by competent authors), there are four short discourses available on each of these 'truths.' What do they signify? A clear definition and/or analysis of each of the components. This is where the importance of the methodology relies. In the first component, for example, Dukkha or suffering is identified as the relevant problem and it is defined and analysed in seven different ways ${ }^{18}$. This is what a modern day researcher would or should do in detail in any research. It is like identifying and defining the research problem thoroughly in a scientific manner as the starting point.

Likewise, in the second component of Samudaya, the causes for Dukkha are investigated and identified in three dimensions of the same primary cause of Thanha (greed). One may argue that causal analysis here is rather reductionist. However, that is the way it was put forward. This does not preclude any researcher today following the same methodology in analysing the causes in a multiple manner. The Buddha did not at all present a dogma even in the case of the FNT. According to the logic of the methodology presented, the solutions should follow cogently from the analysis of the causes. The eradication of the cause or causes is what is presented as Nirodha in the exposition. This may be the reason why the Buddhist methodology is closely equated with the methodology or methodologies of medical science, traditionally and today. It may be the case that the same sequence might not be followed in Social Science research. Most of the Social Science research in Sri Lanka and elsewhere focus mainly on revealing new information, facts and, at best, arguments, but not completely resolving social issues or problems. The researchers tend to leave 'problem solving' to politicians and other social actors. While this can be the case in practice to a great extent, there is no inhibition for them to put forward solutions or proposing ways and means of resolving key issues and problems in society, economy or in politics. The Buddhist methodology of the FNT could be an inspiration for leading the Social Science research in this direction.

The last and the most important component of the Buddhist methodology is Magga, the pathways for solutions. Considering that the major problem that humanity is facing is Dukkha, the Buddha enunciated the noble eightfold path: (1) right view; (2) right resolve; (3) right speech; (4) right action; (5) right livelihood; (6) right effort; (7) right mindfulness; and (8) right concentration. As previously mentioned, while these pathways are recommended particularly for righteous behavior, some of them may have application for researchers as well. Right view, right speech and right concentration are particularly applicable. It is widely believed that some, if not all, paths are directly connected with the purposes and acquisition of knowledge ${ }^{19}$. As Gowans (2003: 173) has said,

"Right view is essentially the possession of knowledge. It should be expected that this is the first step of the Eightfold Path since, in the twelvefold formula of dependent origination, ignorance is the first condition that ultimately leads to suffering."

However, the knowledge that the Buddha talked about is 'not knowledge per se or mere knowledge that some propositions are true'. This should be kept in mind when his methodology is applied or if applied for the purposes of research today. Otherwise it could be a distortion of Buddhism ${ }^{20}$.

The merit of the FNT for research methodology is that it supplies a viable framework and methodology for scientific investigation although not elaborated for obvious reasons of that time. The teachings of the Buddha were oral and they were transformed into suttas and kept memorised by the disciples. Therefore, it is possible that some of the contents were lost. When they were written after some centuries, there appeared several versions, depending on the different schools of thought and conviction. By that time, as Buddhism had become an organised religion, what is lost could be considered mostly the 'scientific and philosophical' content. Yet, what is remaining stand as an authentic vision for seeking knowledge and the method could be immensely useful as a research methodology of its own. It is neither a deductive method as Aristotle pronounced, nor purely an inductive method which became prominent since Francis Bacon's time in the West. As I had argued in a previous article 
(Fernando, 2008), it appears to be a system comparable to what the $20^{\text {th }}$ century philosopher John Dewey advocated combining both the deductive and the inductive systems of logic for scientific investigation. To say so also could be an underestimation of the originality of the Buddha's system which has a clearly different design on how an investigation on a particular phenomenon could proceed especially investigating causes (Samudaya), identifying solutions (Nirodha) and developing pathways for solutions (Magga). Any research lacking these elements could be considered unscientific according to the Buddha's theory of knowledge.

\section{KALAMA-SUTTA OR 'CHARTER OF FREE INQUIRY'}

What is the meaning of Dukkha in the methodology of the FNT? We have already inquired about it, yet it is necessary to reiterate it in the present context. It cannot be merely the condition of 'suffering'. Going by the meanings of other components, it can be any condition or problem that humans encounter which needs to be probed and resolved. It also cannot be a 'major premise' similar to the Aristotelian logic through which other inferences could be made. Kalama-sutta in Anguttara Nikaya shows us that the Buddha was not in support of any such dogmatic or broad general premises. That is why it is considered a 'Charter of Free Inquiry' ${ }^{21}$. The Buddha was opposed to blind faith, dogmatism and belief spawned through spurious reasoning. The discourse was delivered to Kalama of Kesaputta while he was on a visit to that particular locality. Kalama asked the Buddha:

"Sir, there are some recluses and brahmanas who visit Kesaputta. They explain and illumine only their own doctrines, and despise, condemn and spurn others' doctrines. Then come other recluses and brahmanas, and they too, in their turn, explain and illumine only their own doctrines, and despise, condemn and spurn others' doctrines. But, for us. Sir, we have always doubt and perplexity as to who among these venerable recluses and brahmanas spoke the truth, and who spoke falsehood." (Rahula, 1978: 2)

Then the Buddha gave them advice which explicates his 'theory of knowledge' and advocates very clearly the value of 'independent investigation' and 'verification through personal observation'. He said:

"Yes, Kalamas, it is proper that you have doubt, that you have perplexity, for a doubt has arisen in a matter which is doubtful. Now, look you Kalamas, do not be led by reports, or tradition, or hearsay. Be not led by the authority of religious texts, not by mere logic or inference, nor by considering appearances, nor by the delight in speculative opinions, nor by seeming possibilities, nor by the idea: "this is our teacher." (Rahula, 1978: 3)

Then by what? There are different interpretations about his answer. Considering that the main questioning was about moral truths, what is good or bad, or religious views, many translations give similar meaning to what Ven.Walpola Rahula has recorded:

"But, O Kalamas, when you know for yourselves that certain things are unwholesome (akusala), and wrong, and bad, then give them up...And when you know for yourselves that certain things are wholesome (kusala) and good, then accept them and follow them." (Rahula, 1978: 3)

What is highlighted here is personal checking and verification. As Jayatilleke (2008: 390) has also pointed out, that according to the Buddha, 'everything should be tested and verified before accepting'. He further quotes Tibetan sources referring to Kalama-sutta which say;

"Just as wise men (test a claim to be gold) by burning, cutting and rubbing (on a touchstone), [even] my statements, O monks, should be accepted after examination and not out of respect for me." (Jayatilleke, 2008: 390)

There is a considerable difference between the first attributed answer and the second. The first answer is about a personal judgement and allowing free will or free choice between different theories or teachings. However, the second is more precise and beyond a personal judgement or opinion. 'Burning, cutting and rubbing on a touchstone' reveal something akin to rigorous scientific investigation or testing beyond one's value judgements. Kalama-sutta appears to apply more for verifying existing knowledge and could be useful as a guideline for literature reviews or theoretical overviews in modern day research work. The basic lesson is not to take anything written or available on their face value and to scrutinise thoroughly for verification.

\section{DEPENDENT ORIGINATION OR PATICCASAMUPPADA}

Like many other theories and propositions in Buddhist philosophy, Paticcasamuppada or 'dependent origination' has also acquired different interpretations throughout centuries (Cox, 1993: 119). However, those are in respect 
of some details, and the main thesis undoubtedly is the following agreed by almost all the interpretations and texts.

"When this is, that is, from the arising of this, that arises; when this is not, that is not, from the cessation of this that ceases."

The above twofold abstract statement is usually presented (in many ancient texts) with a list of conditioned and conditioning factors (usually twelve), which are both independent and dependent. Our concern here is not particularly about the veracity of those factors but the discernible causallogic in them as a methodology. As a matter fact, it is important to report that 'consciousness' (Vinnana) plays a major role in the process of this causality. There are other factors which are physical, material or even determinant. The evolution of different interpretations particularly on the underlying factors (see discussion by Cox, 1993: 123126) reveal that even today, depending on the context within which the above causation is applied or discussed, the researchers could identify their own dependent or independent variables. There is no question that the original interpretations of twelve factors gave emphasis on subjective dimensions, as the explanations were related to human 'suffering'. However, this does not preclude the identification of social, economic, political or environmental factors for causation, as they may be relevant particularly in social research and studies when the 'dependent origination' methodology is applied.

The logic of the causation is the most amazing in the 'dependent origination'. As the Nidanavagga of Sanyuttanikaya has stated, as quoted by Cox (1993: 126), "There are motivations in dependence upon ignorance, there is perceptual consciousness in dependence upon motivations" and so on. The most important logic or reasoning is the following:

"But from the complete turning away from, the complete cessation of ignorance, there is the cessation of motivations, and from the cessation of motivations, there is the cessation of perpetual consciousness." (Cox, 1993: 126)

What a beautiful argument and logical reasoning which could be applied or useful for any social researcher today. With these comments we can turn to more mundane interpretations by Snyder (2006: 56-57). According to him, the 'dependent origination' theory is something in between 'free-will' and 'determinism.' If I may put it in Fonseka's (2011) terms, between 'rationalism' and 'empiricism'. Both are partially correct, but not totally, and this means partially incorrect. The Buddha's dependent origination theory allows us to keep an open mind and understand and identify the exact play of 'freewill' and/or natural 'determination' in a given context. Even there can be conjunction of conditions. This also means that no single cause could produce an effect. There is always the collection of conditions. It might be opportune to sum up our discussion on dependent origination by quoting Snyder (2006: 57), who himself is a sociologist, as follows.

"Natural and social scientists have always looked to multiple causes as rarely does any effect result mostly from one cause. They use control groups and other techniques to isolate possible causes to at least narrow their theories down to fewer possible explanations. This is fully compatible to the principle of Dependent Origination."

\section{CONCLUSION}

The preparation of this article has been a learning process for the author himself given the paucity of material available on the subject of 'Buddhism as a methodology', let alone 'Buddhism as a research methodology', among other reasons. The author, initially based on Ven. (Dr.) Walpola Rahula's numerous and illuminating analyses, had come to the hypothesis that Buddhism primarily is a methodology or approach to seek and uncover knowledge more than anything else. It was this hypothesis that was examined, analysed or 'tested' in this article exclusively pertaining to research methodology. The modus operandi followed in this article was first to investigate the Buddha's contribution to the 'theory of knowledge' in a historical context, in comparison to the comparable Greek philosophical contributions of the same period. While there was no attempt to say what was best or correct, it was nevertheless pointed out, among other things, that the Buddhist logic of 'four alternatives' (Catuskoti) perhaps is more useful in understanding or cognising complex realities.

The main focus of the article, however, was on the methodology of the Four Noble Truths. Based on the evidence available and the way the reasoning, logic and the structure of the FNT could be analysed, it is concluded here, as elaborated in the body of the article, that the methodology of the Four Noble Truths could be immensely valuable in Social Science research in particular where Dukkha could be considered as the identification of the research problem/s, Samudaya as the analysis of the causes, Nirodha as the identification and detection of necessary solutions, and Magga as the proposed pathways or recommendations to the final 
resolution of those problems. Such a methodology or a research design undoubtedly goes beyond the conventional trends in Social Science research, increasingly becoming stereotypical and divorced from fundamental issues and problems of human beings and society. Although the first two stages or components are adequately followed in many Social Science research today, the last two components of 'discovery of solutions' and 'innovating resolutions' are often neglected. The key emphasis that the Buddha gave on Magga could be considered unique and innovative (i.e. noble eightfold path) in any intellectual or philosophical endeavor throughout centuries since his time.

The article also reinforced the methodological validity of the Buddha's teachings relevant to Social Science research by discussing Kalama-sutta or the 'Charter of Free Inquiry' and, more importantly, Paticcasamuppada or 'dependent origination' as a useful theory of causality. It could also be concluded that while the vision and insights of Kalama-sutta are important in verifying and authenticating the existing knowledge or theories on a subject, the methodology of the Four Noble Truths is important in uncovering and investigating new knowledge in social research. The 'dependent origination' on the other hand could be considered a link between the two levels of inquiry of knowledge of the existing and the new. There are many other aspects or revelations of the Buddha (i.e. mindfulness and bare attention) that could be considered directly and indirectly relevant to research methodology which were not discussed in this article for the reasons of brevity and focus. Those could be left for future investigations. More importantly, the application of the Buddhist methodology, or particularly the FNT, for conflict analysis, conflict resolution and peace building are undoubtedly profound areas for future research and investigation.

\section{END NOTES}

1. The above references/sources give only a glimpse. If we take many scientists involved in this enterprise, in some of these edited volumes, the number is considerable.

2. As Mike Wall of Space.co reported (5 August 2015), astronomers have found the newest and the farthest galaxy now named as EGSY8p7. It is also worth mentioning Agganna-sutta (the book of genesis in Dighanikaya) along with Saleyaka-sutta (in Majjhimanikaya) which explains 'the planes above the human plane in ascending order'. This is a valuable comment from a reviewer.
3. As Einstein said in his essay on Religion and Science (1954: 38), "The beginning of cosmic religious feeling already appears at an early stage of development, e.g. in many of the Psalms of David and in some of the Prophets. Buddhism, as we have learned especially from the wonderful writings of Schopenhauer, contains a much stronger elements of this."

4. A similar position was expressed by Bhikkhu Bodhi later (Fonseka, 2011).

5. The five characteristics that Muller identified were: 'the belief in a divine power; the acknowledgement of sin; the habit of prayer; the desire to offer sacrifice; and the hope of a future life' (Lectures on the Science of Religion, 1873).

6. A previous preliminary study by the author was "An Introduction to Research Methodology: Western and Buddhist Perspectives" (2008) [online] Available from: http://documents.mx/documents/ an-introduction-to-research-methodology-by-proflaksiri-fernando.html [Accessed on $29^{\text {th }}$ September 2016].

7. Two other thinkers of the same period were Confucius and Jeremiah (See Armstrong, 2007).

8. Buddha's observations through questioning on the dispute between Sakya and Koliya clans over the water in Rohini river and his discourse on peace is one example. (See H. Miall et al., 2002: 65).

9. What is lacking in this interpretation is the importance of the 'Four Noble Truths' themselves constituting and explicating a scientific method.

10. A similar institute for Buddhist studies was Nalanda (university) from around the $5^{\text {th }}$ century CE to 1200 CE.

11. Perhaps the best translation of The Organon can be considered by Jones (2012) which was used for this study.

12. With apologies to Aristotle for any unintended distortion.

13. Both examples are from and/or attributed to Aristotle.

14. The original work of Jayatilleke dates back to 1963 while Ven. Nyanaponika Thera's original publication 
was in 1971. For this article, new editions of 2008 for both were used.

15. Translated from Pali by Thanissaro Bhikkhu (1993), Alternative Translations, [online] Available from: http://www.accesstoinsight.org/tipitaka/sn/sn56/ sn56.011.than.html [Accessed on 29 $9^{\text {th }}$ September 2016]. All quotations for the Four Noble Truths that follows are from this source.

16. The present author was one of the drafters of the UNESCO recognised "The Lima Declaration of Academic Freedom and Autonomy of Higher Education Institutions" and an Editor of Academic Freedom 1990 (Zed Books, 1990).

17. As one of the reviewers pertinently pointed out, the thesis of Visuddhi Magga has a particular Sri Lankan relevance as it was authored by Buddhagosa Thera. As the anonymous reviewer noted to the author, 'the thesis was written three times, and after strict and due reviews, it was finally accepted by Mahaviara school. The work itself uses "Magga" for the title of the work which indicates the significance of "The Uncontaminated Way (Method)".

18. It goes like the following: "Now, this, O Bhikkus is the Noble Truth of Suffering. Birth is suffering, decay is suffering, disease is suffering, death is suffering, to be united with the unpleasant is suffering, to be separated is suffering, not to get what one desires is suffering..."

19. Noble eightfold path of course was not without critics. Uche Ephraim Chuku (2007) said "This magical eightfold path was said to consist of right view, right thought, right speech, right action, right mode of living, right endeavor, right mindfulness and rights concentration. What a wonderful grammar! Remarkably, "Right Knowledge" was conspicuously missing from his so-called noble eightfold-path to niravana." (Religion of the Rustic Gods vs the Gospel Truth. iUniverse. New York).

20. It is important to mention that the present author keeps an open mind about the controversial debate whether even Nirvana could be 'scientific' or empirically verifiable. There are important insights by Asanga Tilakaratne (1993) on the subject.

21. A Chroniker Press Book (2012) Epitome of the Pali Canon. pp: 143. This was a saying by Soma Thera.

\section{ACKNOWLEDGEMENT}

The author wishes to thank the two academic reviewers for their valuable and objective comments. Any inadvertent errors still remaining are of the author's responsibility.

\section{REFERENCES}

Armstrong, K. (2007) The Great Transformation: The World in the Time of Buddha, Socrates, Confucius and Jeremiah. London: Atlantic Books.

Barash, D. P. (2013) Buddhist Biology: Ancient Eastern Wisdom Meets Modern Western Science. Oxford: Oxford University Press.

Boyce, M. (ed.) (1984) Textual Sources for the Study of Zoroastrianism. Chicago: Chicago University Press.

Cho, F. \& Squier, R. K. (2015) Religion and Science in the Mirror of Buddhism. Routledge: New York.

Chuku, U. E. (2007) Religion of Rustic Gods vs the Gospel Truth. New York: iUniverse.

Cox, C. (1993) Dependent Origination: It's Elaboration in Early SarvastivadinAbhidharma Texts. In Ram Karan Sharma (ed.). Research in Indian and Buddhist Philosophy. Delhi: Motilal Bandarsidass Publications.

Davids, R. (2005) [1896] Buddhism: Its History and Literature. New York: Cosimo Classics.

De Poly, E. \& Gitlin, L. N. (2011) Introduction to Research: Understanding and Applying Multiple Strategies. St. Louis: Elsevier.

De Silva, P. (1973) Buddhism and Freudian Psychology. Singapore: Singapore University Press.

Dissanayake, P. (1999) Buddhist Political Theory. Colombo: Sadeepa Books.

Dockett, K. H., Dudley-Grant, G. R. \& Bankart, C. P. (eds.) (2004) Psychology and Buddhism: From Individual to Global Community. New York: Kluwer Academic Publications.

Dunne, J. (2015) Buddhist Styles of Mindfulness: A Heuristic Approach. In Brian D. Ostafin, Michael D. Robinson \& Brian P. Meier (eds.). Handbook of Mindfulness and Self-Regulation. New York: Springer.

DOI: http://dx.doi.org/10.1007/978-1-4939-2263-5_18

Einstein, A. (1954) Religion and Science. Ideas and Opinions. New York: Crown Publishers. 
Evans, B. (ed.) (1994) Buddhist Economics: A Middle Way for the Market Place. Bangkok: Buddhadharmma Foundation.

Fernando, L. (2008) An Introduction to Research Methodology: Western and Buddhist Perspectives. (NCAS Lecture). [Online] Available from: http://documents.mx/documents/ an-introduction-to-research-methodology-by-prof-laksirifernando.html [Accessed: 29 ${ }^{\text {th }}$ September 2016].

Flanagan, O. (2007) Science for Monks: Buddhism and Science. Massachusetts: MIT Press.

Fonseka, C. (2011) Buddhism and Empiricism. Sri Lanka Guardian. [Online] 17 $7^{\text {th }}$ August 2011. Available from: http://www.srilankaguardian.org/2011/08/buddhism-andempiricism.html [Accessed: 29 $9^{\text {th }}$ September 2016].

Galtung, J. \& Ikeda, D. (1995) Choose Peace. London: Pluto Press.

Gard, R. A. (1956) Buddhist Political Thought: A Study of Buddhism in Society. Nakhon Pathom (Thailand): Mahamakut University.

Gowans, C. W. (2003) Philosophy of the Buddha. London: Routledge.

Hook, S. (2008) John Dewey: An Intellectual Portrait. New York: Cosimo Classics.

Jayatilleke, K. N. (1984) Buddhism and the Scientific Revolution. In Buddhadasa Kirthisinghe (ed). Buddhism and Science. Delhi: Motilal Bandarsidass Publications.

Jayatilleke, K. N. (2008) [1963] Early Buddhist Theory of Knowledge. Oxon: Routledge.

Jones, R. B. (2012) The Organon: The Works of Aristotle on Logic. Charleston: Create Space.

Kalupahana, D. J. (1976) Buddhist Philosophy: A Historical Analysis. Honolulu: Hawaii University Press.

Kothari, C. R. (2004) Research Methodology: Methods and Techniques. New Delhi: New Age International.

Lopez, D. S. (2008) Buddhism and Science: A Guide for the Perplexed. Chicago: Chicago University Press.

Lopez, D. S. (2012) The Scientific Buddha: His Short and Happy Life. New Haven: Yale University Press.

D O I : h t t p : / d x.d o i.org/ 10.7208 chicago/9780226493244.001.0001

Mookerji, R. K. (2003) Ancient Indian Education: Brahmanical and Buddhist. Delhi: Motilal Bandarsidass Publications.
Mun, C. \& Green, R. (ed.) (2006) Buddhist Exploration of Peace and Justice. Honolulu: Blue Pine.

Nithiyanandam, V. (2004) Buddhist System of Education. New Delhi: Global Vision Publishing House.

Nyanaponika Thera. (1962) The Heart of Buddha's Meditation. London: Rider \& Co.

Rahula, W. (1978) What the Buddha Taught. London: Gordon Fraser.

Ratnapala, N. (1997) Buddhist Political Theory and Practice. Colombo: Sarvodaya.

Ricard, M. \& Thuan, T. X. (2001) The Quantum and the Lotus: A Journey to the Frontiers where Science and Buddhism Meet. New York: Three Rivers Press.

Rodgers, P. A. \& Yee, J. (ed) (2015) The Routledge Companion to Design Research. London: Routledge.

Schuman, M. (2015) Confucius and the World He Created. New York: Basic Books.

Siderits, M. (2007) Buddhism as Philosophy: An Introduction. Aldershot: Ashgate Publishing.

Sivaraksa, S. (2011) The Wisdom of Sustainability: Buddhist Economics for the $21^{\text {st }}$ Century. London: Souvenir Press.

Snyder, D. (2006) The Complete Book of Buddha's Lists Explained. Las Vegas: Vipassana Foundation.

Taniguchi, S. (1994) Methodology of Buddhist Biomedical Ethics. In Paul Camenisch (ed.). Religious Methods and Resources in Bioethics. New York: Springer.

DOI: http://dx.doi.org/10.1007/978-94-015-8362-6_2

Thanissaro Bhikkhu. (1993) Dhammacakkappavattna Sutta: Setting the Wheel of Dhamma in Motion. [Online] Available from:http://www.accesstoinsight.org/tipitaka/sn/sn56/ sn56.011.than.html [Accessed: 29 ${ }^{\text {th }}$ September 2016].

Tilakaratne, A. (1993) Nirvana and Ineffability: As Study of the Buddhist Theory of Reality and Language. Colombo: University of Kelaniya.

Wallace, A. (ed). (2003) Buddhism and Science: Breaking New Ground. New York: Columbia University Press.

Wallace, V.(2001)TheInner Kalacakratantra: ABuddhist Tantric View of the Individual. Oxford: Oxford University Press. DOI: http://dx.doi.org/10.1093/0195122119.001.0001 